\title{
IMPLEMENTASI PENDISTRIBUSIAN \\ DANA ZAKAT INFAQ DAN SHADAQAH \\ (ZIS) PERBANKAN SYARIAH UNTUK PEMBERDAYAAN USAHA KECIL MIKRO (UKM) DI MALANG
}

\author{
Indah Yuliana \\ Fakultas Ekonomi Universitas Islam Negeri Maulana Malik Ibrahim \\ Malang, Jl. Gajayana No. 50 Malang 65144, Telp. 0341-551354,558882
}

\begin{abstract}
One of the organization models of tithe, grant, and charity fund in syariah banking is called Qardhul Hasan. Its organization model is giving loan to UKM without sharing outcome. The fund derives from cutting the tithe from officials and employees of syariah bank and also from bank customers. Because the grant is aimed for the distribution of economy, its allocation must give advantages toward low society. The research is intended to study about the implementation of the ZIS fund distribution by syariah banks in the efforts of empowering UKM. The research is a qualitative - descriptive research where the data was obtained from field direct observation and literature information. The result shows that the organization model and ZIS of syariah bank is conducted by cooperation between BMT and mosques. The distribution of ZIS fund has both consumptive and productive type, where the productive type is expected to be distributed to small-micro industries. The fund given to this kind of industry is aimed to raise the capital, so that they could improve their small industries. As soon as those small industries succeed in improving themselves, their income will increase and they could upgrade their status from mustahiq to muzakki.
\end{abstract}

Produk Qardhul Hasan merupakan salah satu dari produk jasa yang ada di perbankan syariah. Penerapan prinsip qardh dalam perbankan syariah adalah untuk pinjaman tanpa imbalan. Hal ini dilakukan misalnya untuk pinjaman antar bank syariah tanpa bunga. Qardh juga diterapkan untuk pinjaman 
kepada nasabah yang mengelola usaha sangat kecil. Penelitian ini mengarahkan perhatian pada kajian tentang implementasi pendistribusian dana ZIS yang dilakukan oleh bank-bank syariah bagi pemberdayaan ekonomi usaha kecil (UKM). Data yang digunakan dalam penelitian ini diperoleh dari lapangan melalui observasi langsung sebagai data primer, dan juga menggunakan informasi yang telah terdokumentasikan, baik berupa buku, jurnal dan makalah ilmiah maupun hasil penelitian sebagai data sekunder. Penyaluran dana ZIS Bank Syariah dilakukan dengan mengadakan kerjasama dengan BMT dan masjid. Penyaluran dana ZIS tersebut bersifat konsumtif dan produktif. Untuk pendanaan yang bersifat produktif disalurkan kepada pemberdayaan usaha kecil dan mikro. Pemberdayaan yang dilakukan dengan dana ZIS tersebut adalah dengan memberikan modal guna mengembangkan usaha dan memulai usaha. Penambahan modal ini diberikan pada usaha kecil dan mikro agar bisa mengembangkan usaha yang telah dirintisnya. Bila usahanya berkembang, maka pendapatan akan naik dan diharapkan akan adanya transformasi dari penerima bantuan, dengan kata lain dari mustahiq menjadi muzakki.

Key words: model of tithe grand and charity (ZIS)

\section{Pendahuluan}

Krisis ekonomi yang dialami Indonesia, kini semakin membangkitkan kesadaran akan peranan usaha kecil dan menengah sebagai tulang punggung perekonomian Indonesia. Sektor usaha kecil memilki peranan yang sangat strategis dalam pembangunan nasional, baik secara kualitas maupun kuantitasnya dalam meningkatkan percepatan dan penyerapan tenaga kerja serta mewujudkan pemerataan hasil-hasil pembangunan. Pada sisi lain di sektor keuangan mikro, sebenarnya ada kegiatan individu dari masyarakat yang sudah memperhatikan hal tersebut, sehingga kelompok individu tersebut memberikan permodalan yang dibutuhkan UMK. Individu tersebut sering dikenal masyarakat umum sebagai rentenir. Namun demikian keberadaan rentenir itu tidak membawa kemaslahatan bagi masyarakat pada umumnya. Dalam praktek rentenir terdapat permasalahan, diantaranya adalah bentuk permodalan yang dilakukan rentenir. Para rentenir biasanya meminjamkan uang mereka kepada peminjam dengan beberapa ketentuan yang mengikat, antara lain penentuan tingkat bunga yang tinggi dan jangka waktu yang relatif pendek. Praktek rentenir ini secara tidak langsung belum memberikan solusi permasalahan bagi rakyat kecil, akan tetapi justru menambah masalah perekonomian mereka yang sangat kompleks.

Dalam prinsip Islam, kekayaan harus menyandang sistem kesejahteraan yang bertumpu pada zakat, infaq dan shodaqah sebagai bentuk syukur atas 
segala yang dianugerahkan Tuhan. Selain sebagai sarana untuk menyucikan jiwa dan harta, juga merupakan tip bagi jaminan perlindungan, pengembangan dan pengaturan peredaran serta distribusi kekayaan. Cara memanfaatkannya didasarkan pada fungsi sosialnya bagi kepentingan masyarakat yang menyentuh kalangan miskin maupun kaya (Qardhawi, 1995: 37). Di dalam harta orang kaya terdapat harta orang miskin dan penekun agama (sabilillah) yang harus dikeluarkan dalam bentuk zakat, infaq dan shodaqah dan sebagainya. Perintah menafkahkan harta guna membantu mereka yang kurang beruntung dan tekun menegakkan syiar agama merupakan ibadah berdimensi prinsip keadilan sosial dan pemerataan kesejahteraan. Zakat dan sistem waris mengarah pada ditribusi harta yang egaliter (orang yang tak mau mengeluarkan zakat boleh dikenai tinda Sebagai akibat dari penunaian zakat, harta kekayaan selalu beredar di tengah masyarakat. Upaya untuk memperoleh kemajuan ekonomi secara merata bukan kejahatan dalam pandangan Islam. Bahkan itu menjadi sebuah kebaikan bila diseimbangkan dan diniatkan mendapat kebaikan (Khaf, 1995: 2-4).

Ibadah zakat adalah salah satu bentuk ibadah seorang mukmin yang mempunyai komitmen tinggi dengan keimanannya, yang dapat mengangkat derajat ekonomi umat Islam, jika benar-benar dikelola secara profesional dan proporsional. Setidaknya ashnaf (golongan) delapan yang disebutkan al Quran (fakir, miskin, panitia zakat, muallaf, budak, orang yang hutang, sabilillah, ibnu sabil) mendapat bagian zakat, dengan lebih memperioritaskan golongan yang lebih memerlukan. Pendistribusian zakat, yang selama ini sudah berlaku di masyarakat muslim, pada umumnya lebih bersifat konsumtif. Pada malam idul fitri misalnya, panitia zakat masjid atau mushalla dengan anggota kelompoknya membagi-bagikan beras atau uang ke rumah-rumah orang yang tidak mampu, dan memberikannya kepada abang-abang becak di jalan-jalan secara instan. Memang, sepintas lalu, apa yang dilakukan oleh panitia zakat ini mampu sedikit membantu beban ekonomi para dlu'afa' tersebut dalam waktu beberapa hari. Karena anggaran makan selama 1-2 hari telah tercukupi dengan pemberian panitia zakat. Namun, kemudian muncul pertanyaan, apakah model pendistribusian seperti ini mampu mengubah nasib ekonomi mereka. Tentu masih jauh dari harapan yang kita idam-idamkan selama ini, yakni bagaimana mengubah nasib ekonomi para mustahiq (orang yang berhak menerima zakat), yang asalnya hanya sekedar penerima zakat, menjadi muzakki (orang yang mengeluarkan zakat), dan bagaimana bisa merubah status sosial ekonomi para muzakki. 
Berdasarkan data yang ada, pengumpulan dana ZIS (Zakat, Infak dan Sadakah) tumbuh rata-rata lebih dari 50 persen sepanjang 2002-2009. Puncak pertumbuhannya pada tahun 2005 dan 2007 dengan pertumbuhan lebih dari 95 persen dengan jumlah pengumpulan mencapai Rp 295,32 miliar dan Rp 740 miliar per tahun (The National Board of Zakat, 2009). Pertumbuhan pengumpulan ZIS yang hampir mencapai 100 persen ini disebabkan adanya tsunami Aceh 2005 dan gempa Yogyakarta 2007. Ternyata gempa alam yang sempat memporak-porandakan sebagian wilayah negeri ini cukup efektif untuk menggugah kesadaran masyarakat dalam berzakat, berinfak, dan bersadakah.

Sementara itu, kiprah BAZIS (badan amal, zakat, infaq dan shadaqah) yang selama ini ditunggu-tunggu masyarakat muslim, kelihatannya juga kurang maksimal dan belum menyentuh pada persoalan inti. Bisa jadi, dana yang ada sangat terbatas (tidak ada kesesuaian antara dana yang terkumpul dengan orang-orang yang berhak menerima). Atau bisa jadi, proses pendistribusian zakat tersebut masih bersifat konsumtif, yang hanya bisa membantu operasional hidup para mustahiq sekian hari saja, lain tidak. Karena itulah, pendistribusian zakat secara produktif yang sudah digembar-gemborkan oleh banyak pihak sudah tidak bisa ditunda-tunda lagi pelaksanaannya. Bagaimana misalnya, dana zakat yang terkumpul didistribusikan kepada para mustahiq, untuk dijadikan sebagai modal usaha.

Dari modal usaha ini, para mustahiq, para dluafa' diharapkan mampu membantu usaha ekonomi mereka, sehingga dapat meningkatkan status ekonomi dan taraf hidup mereka. Namun, idealitas pendistribusian zakat produktif ini, tentu tidak bisa berjalan dengan efektif, jika prosesinya dilakukan secara individu dan kurang terencana secara matang, baik segi managerial usahanya atau segi memilih sasaran mustahiq-nya. Dan yang tidak kalah pentingnya adalah bagaimana memantau perkembangan usaha mustahiq dan menindaklanjutinya, serta selalu membantu seluruh kesulitan yang dihadapinya. Pendistribusian zakat yang bersifat produktif seperti ini, diharapkan mampu membantu meningkatkan taraf hidup umat Islam pada khususnya, dan rakyat Indonesia pada umumnya. Dengan usaha produktif yang modalnya disuntik dari dana zakat, para mustahiq mendapat pekerjaan dan terhindar dari pengangguran. Dari sini, zakat diharapkan dapat merubah status ekonomi para mustahiq tadi, dari status penerima zakat (mustahiq) menjadi muzakki (orang yang mengeluarkan zakat); yang asalnya hidup serba kekurangan menjadi orang yang lebih mampu secara ekonomis, yang pada gilirannya nanti akan 
merubah taraf pendidikan mereka. Dana zakat, infaq dan shodaqah yang terkumpul harus didayagunakan.

Pendayagunaan adalah pemanfaatan dana zakat, infaq dan shodaqah sedemikian rupa sehingga memiliki fungsi sosial dan sekaligus fungsi ekonomi (konsumtif dan produktif) (Departemen Agama RI, 2002: 234-244). Sasaran yang harus dicapai dari pendayagunaan tersebut adalah timbulnya keberdayaan umat. Dengan kata lain, sasaran pendayagunaan adalah pemberdayaan. Pemberdayaan adalah upaya memperkuat posisi sosial dan ekonomi dengan tujuan mencapai penguatan kemampuan umat melalui dana bantuan yang pada umumnya berupa kredit untuk usaha produktif, sehingga usaha kecil sanggup meningkatkan pendapatannya dan juga membayar kewajibannya (zakat) dari hasil usahanya atas kredit yang dipinjamnya. (Kesepakatan para ahli hukum zakat dalam Simposium Internasional tentang Zakat ke-7, di Yaman Oktober 2000). Tujuan penelitian ini adalah untuk menggambarkan implementasi pendistribusian dana ZIS yang dilakukan oleh Bank Syariah untuk pemberdayaan ekonomi usaha kecil (UKM) di Malang.

\section{Produk Qardhul Hasan}

Produk Qardhul hasan merupakan salah satu dari produk jasa yang ada diperbankan syariah. Penerapan prinsip qardh dalam perbankan syariah adalah untuk pinjaman tanpa imbalan. Hal ini dilakukan misalnya untuk pinjaman antar bank syariah tanpa bunga. Qardh juga diterapkan untuk pinjaman kepada nasabah yang mengelola usaha sangat kecil. Untuk pembiayaan sangat khusus ini sumber dananya diambil dari dana sosial seperti zakat, infak dan sadaqah. Jika nasabah mengalami musibah dan tidak dapat mengembalikan, maka bank dapat membebaskannya (Antonio, 1999: 253).

Qard adalah apa yang diberikan dari harta yang terukur yang dapat ditagih/ dituntut, atau akad yang dikhususkan yang dikembalikan pada membayar harta yang terukur kepada orang lain agar dikembalikan sepertinya (Tim Pengembangan Perbankan Indonesia, 2002: 217).Pinjaman qard al hasan adalah salah satu kegiatan bank syariah dalam mewrujudkan tanggung jawab sosialnya sesuai dengan ajaran Islam. Untuk kegiatan ini bank tidak memperoleh penghasilan karena bank dilarang untuk meminta imbalan apapun dari para penerima qard (Zainul, 2002: 61).

\section{Mengurangi Kemiskinan dengan Dana ZIS (dana Qardhul hasan)}

Menurut Bank Dunia kemiskinana adalah "poverty is concerned with absolute 
standard of living of part of society the poor in equality refers to relative living standard across the whole society (Sumodiningrat dkk,1999: 12). Kemiskinan sesungguhnya telah menjadi masalah yang akut sejak lama, dan hampir dapat dikatakan sebagai "kenyataan abadi" dalam kehidupan umat manusia. Kemiskinan antara lain dapat diukur dengan menggunakan rasio antara tingkat pendapatan dan tingkat kebutuhan dasar minimum. Jika pendapatan tidak dapat memenuhi kebutuhan dasar minimum, maka orang atau rumah tangga tersebut dikatakan miskin. Dengan demikian, kemiskinan dapat diukur dengan membandingkan tingkat pendapatan orang atau rumah tangga dengan tingkat kebutuhan dasar minimum yang harus dipenuhi.

Kemiskinan dibagi menjadi dua: absolut dan relatif. Miskin absolut apabila pendapatan lebih rendah daripada garis kemiskinan absolut yang ditetapkan, atau dengan kata lain jumlah pendapatan tidak cukup untuk memenuhi kebutuhan hidup minimum sebagaimana dicerminkan garis kemiskinan absolut tersebut. Sedangkan, kemiskinan relatif adalah keadaan perbandingan antara kelompok pendapatan dalam masyarakat, yakni antara kelompok yang mungkin tidak miskin karena mempunyai tingkat pendapatan lebih tinggi dari garis kemiskinan, dan kelompok masyarakat yang lebih kaya. Dengan kata lain, kaum miskin sebenarnya hanya dapat memenuhi kebutuhan dasar minimum, tetapi jika dibandingkan dengan masyarakat sekitarnya, mereka masih berada dalam keadaan miskin (Esmara,1986: 287).

\section{Perbankan Syariah dalam Pengentasan Kemiskinan}

Perbankan syariah harus ikut mengentaskan kemiskinan dan menanggulangi pengangguran. Sesungguhnya Rasulullah SAW telah mengingatkan kepada kita dalam sebuah Haditstnya agar kita menjadi pembela orang-orang miskin (al Haditst). Tidak boleh kefakiran merajalela di mana-mana karena sesungguhnya kefakiran hanya menyebabkan seseorang kepada kekufuran (al Haditst). Orangorang yang tidak mau mengentaskan kemiskinan yang tidak menganjurkan memberi makan orang miskin adalah pendusta agama. Peran Perbankan Syariah dalam pengentasan kemiskinan dan penanggulangan pengangguran antara lain sebagai berikut:

Melaksanakan lembaga-lembaga agama yang sudah diperintahkan dan diwajibkan kepada orang-orang Islam yaitu ZIS (zakat, infaq dan shadaqah) dan wakaf. Institusi-institusi agama tersebut mempunyai potensi yang luar biasa tetapi tidak pernah dapat dikongkritisasi secara riil di masyarakat. Melalui lembaga perbankan syariah sebagai lembaga yang diyakini dan dipercaya oleh 
masyarakat maka penarikan ZIS\&W tersebut akan dapat dikumpulkan lebih baik dan lebih besar jumlahnya.

Perbankan syariah dapat melakukan pembiayaan terhadap sektor riil dan mikro ekonomi di mana masyarakat miskin berkehidupan ekonomi di dalamnya. Begitu juga perbankan dapat membiayai di bidang pertanian yang sekarang sudah berkembang secara diferensial termasuk pertanian, hydrophonik. Sebagaimana diketahui bidang pertanian dapat menyerap 40\% tenaga kerja nasional yang di dalamnya pada dasarnya kebanyakan masyarakat muslim yang miskin.

Perbankan syariah juga dapat melakukan pembiayaan terhadap pembangunan infrastruktur seperti jalan, listrik, telekomunikasi, irigasi dan lain sebagainya. Pembangunan infrastruktur di pedesaan di mana tinggal orang-orang berada di bawah garis kemiskinan, sarana dan prasarananya masih sangat kurang. Industri yang juga menyerap tenaga kerja yang besar adalah industri manufaktur. Tidak harus dalam skala yang besar dapat dilakukan dalam skala kecil dan menengah. Perbankan syariah juga dapat melakukan pembiayaan terhadap bangunan properti yang juga mampu menyerap tenaga kerja yang lebih besar. Selama ini perbankan syariah banyak berkutat pada pembiayaan bidang konsumsi.

\section{Metode}

Penelitian ini mengarahkan perhatian pada kajian tentang implementasi pendistribusian dana ZIS yang dilakukan oleh Bank Syariah bagi pemberdayaan ekonomi usaha kecil (UKM). Data yang digunakan dalam penelitian ini diperoleh dari lapangan melalui observasi langsung sebagai data primer, dan juga menggunakan informasi yang telah terdokumentasikan, baik berupa buku, jurnal dan makalah ilmiah maupun hasil penelitian sebagai data sekunder. Agar diperoleh hasil yang maksimum, dipilih strategi dan tehnik penelitian yang dipandang tepat dan dapat dipertanggungjawabkan. Adapaun tehnik penelitian yang dimaksud itu meliputi (1) Pendekatan studi, (2) Penentuan lokasi penelitian, (3) Pengumpulan data lapangan, dan (4) Tehnik analisis data. Penelitian ini merupakan studi kasus yang bersifat analisis diskriptif. Model penelitiannya adalah dengan menggunakan model survei. Selain itu, penelitian ini juga sengaja memilih pendekatan kualitatif yaitu jenis pendekatan penelitian yang tidak saja berambisi mengumpulkan data dari sisi kuantitasnya, tetapi sekaligus ingin memperoleh pemahaman lebih mendalam yang berhasil direkam untuk diteliti. Persoalan implementasi pendistribusian dana ZIS 
yang dilakukan oleh Bank Syariah bagi pemberdayaan ekonomi usaha kecil (UKM) yang selama ini dilaksanakan oleh bank syariah. Maka dipandang lebih tepat diteliti dengan pendekatan kualitatif untuk memperoleh jawaban yang lebig bersifat mementingkan aspek kedalaman, dan bukan hanya berorientasi pada keluasan. Penelitian ini mengarahkan perhatian pada implementasi pendistribusian dana ZIS yang dilakukan oleh Bank Syariah bagi pemberdayaan ekonomi usaha kecil (UKM) di Malang.

Pengumpulan data lapangan dilakukan dengan menggunakan sarana observasi, wawancara dan studi dokumenter. Observasi ditempuh untuk melihat kondisi objektif realitas sosial baik berupa partisipasi maupun proses yang ada di lapangan, sedangkan wawancara digunakan untuk memperoleh gambaran yang lebih mendalam. Selain itu observasi dan wawancara, peneliti juga melakukan kajian literatur. Hal ini ditujukan untuk memperoleh dasar-dasar teori yang sekaligus digunakan sebagai acuan dalam menganalisis data.

Untuk menguji validitas data yang diperoleh dalam penelitian ini dilakukan dengan beberapa cara. Pertama, mengakrabkan diri dengan dengan sumber informasi. Hubungan yang mendalam antara peneliti dengan informan diharapkan dapat mengurangi subyektifitas informasi yang diberikan. Kedua, banyak melakukan diskusi dengan para ahli dan peneliti lainnya khususnya dengan mereka yang menaruh perhatian pada pendistribusian dana ZIS yang dilakukan oleh Bank Syariah terhadap pemberdayaan ekonomi usaha kecil (UKM). Ketiga, melakukan triangulasi, yaitu melakukan pengecekan terhadap kebenaran informasi yang diberikan dari beberapa narasumber dengan realitas yang ada di lapangan sehingga dapat diperoleh kebenaran yang objektif. (Soeparmono,1993: 24). Selain itu, kebenaran informasi juga diyakinkan kenbenarannya melalui tehnik pengumpulan data yang dapat menjamin kebenaran yang dimaksud.

Strategi pengujian validitas data dalam penelitian kualitatif yang dilakukan ini sesuai dengna apa yang disampaikan oleh Guba dalam Moleong. Guba berpendapat bahwa bahan-bahan dari kalangan akademisi dan praktisi dianggap valid selama data tersebut diseleksi, dikategorisasi dan diuji kesesuainnya dengan data primer sehingga dapat digunakan sebagai pelengkap informasi untuk memperoleh generalisasi yang bersifat ilmiah (Moleong, 2001: 110). Sementara itu, dalam pandangan Moleong bahwa data yang sudah terkumpul hendaknya diperiksa kembali dan dicatat dokumen yang menjadi sumber.

Analisa data dalam penelitian ini dilakukan bersamaan waktunya dengan pengumpulan data itu sendiri dan juga setelah proses pengolahan data. Data 
yang telah diperoleh secara bertahap diklasifikasi, disaring, diidentifikasi, digeneralisasi dan kemudian ditarik kontruksi-konstruksi teoritisnya. Lewat proses itu peneliti berupaya memahami data, menyusun kategorisasi, dan mengidentifikasi karakteristik masing-masing kategori hingga jelas beda satu dengan lainnya.

\section{Pengelolaan Dana ZIS yang Dikembangkan oleh Bank Syariah bagi Pemberdayaan Ekonomi Usaha Kecil Mikro (UKM) di Malang}

\section{Bank Muamalat Indonesia (BMI)}

Bank Muamalat Indonesia dalam menampung dana dan mendistribusikan ZIS membentuk lembaga Baitul Maal Muamalat(BMM). Bagi BMM, kemiskinan di Indonesia tak sekedar terjadi karena struktur dan budaya masyarakat. Kemiskinan juga tak hanya disebabkan oleh sulitnya masyarakat miskin mendapatkan akses sumber permodalan (faktor produksi). Lebih dari itu BMM meyakini bahwa kemiskinan sangat erat kaitannya dengan persoalan keimanan dan ketakwaan masyarakat. Untuk itu Pendekatan pemberdayaan masyarakat dalam mengentaskan kemiskinan, khususnya di bidang ekonomi haruslah dimulai dari pembangunan aspek maknawiyah masyarakat. Yang dimaksud dengan aspek maknawiyah adalah kesadaran yang kuat bahwa keimanan dan ketaqwaan kepada Allah akan mendatangkan keberkahan hidup. Parameter kekuatan iman dan taqwa yang dimaksud adalah terwujud dengan salimul aqidah, sohihul ibadah, matinul khuluk dan salihul muamalat. Dalam membangun aspek maknawiyah, masjid bisa menjadi salah satu medianya. Masjid adalah simbol bagi umat Islam. Masjid dan segala bentuk aktifitas pembinaan (dakwah) umat di dalamnya merupakan metode efektif membangun aspek maknawiyah. Masjid juga merupakan wahana sosialisasi dan mobilisasi umat. Di dalamnya berhimpun berbagai komunitas dan pemimpin opini. sehingga masjid merupakan media atau sarana strategis membangun kesadaran kolektif umat. Baitulmaal Muamalat (BMM) fokus pada pemberdayaan usaha mikro karena:

1. Memberdayakan usaha mikro sangat strategis dalam mewujudkan broad based development / development through equity.

2. Dari 39, 72 juta unit usaha Indonesia, 39,71 juta $(99,97 \%)$ adalah UMKM. Dari jumlah UMKM tersebut $98 \%$ nya adalah usaha mikro.

3. Usaha mikro hanya membutuhkan pengembangan dan peningkatan 
kapasitas bukan penumbuhan, sehingga lebih mudah dan cepat untuk diberdayakan.

4. Pemberdayaan usaha mikro efektif dalam menangani kemiskinan.

BMM fokus terhadap pemberdayaan LKMS karena:

1. Banyak usaha mikro yang not bankable, LKM merupakan akses mudah bagi permodalan usaha mikro.

2. Sistem manajemen LKM di Indonesia banyak yang perlu dibenahi agar mampu melayani kebutuhan usaha mikro secara kontinyu.

3. BMM merupakan lembaga yang berpengalaman dalam program pemberdayaan masyarakat di Indonesia. Hal ini dibuktikan dari riwayat pengalaman BMM menjadi :

a. Pelaksana program P2KER

b. Pelaksna program pembiayaan bergulir IDF

c. Pelaksana Penyaluran Dana Bergulir Syariah (DBS) Menegkop

d. Pelaksna penyaluran dana PKPS BBM dalam bentuk program perkuatan LKMS

e. B-BMT

f. Pendampingan program community development di 30 titik pemberdayaan di Jawa, Sumatra dan Kalimantan.

g. Pelaksana Program CSR PT Indonesia Power

h. Pelaksana Program comdev Wong Solo CISC,HK

i. Kantor perwakilan BMM tersebar di seluruh Indonesia, diantaranya yaitu: Medan, Pekanbaru, Bandung, Semarang, Yogyakarta, Surabaya, Balikpapan.

Pertumbuhan asset BMM mulai tahun 2000 sampai dengan 2005 cukup meningkat. Hal ini dapat dilihat dari tabel dibawah ini.

\begin{tabular}{|l|r|r|r|}
\hline \multicolumn{1}{|c|}{ PERTUMBUHAN ASSET } & \multicolumn{1}{|c|}{$\mathbf{2 0 0 0 - 2 0 0 4}$} & \multicolumn{1}{|c|}{$\mathbf{2 0 0 5}$} & \multicolumn{1}{|c|}{$\mathbf{2 0 0 0 - 2 0 0 5}$} \\
\hline PENGHIMPUNAN (FUNDING) & & & \\
- DANA ZISWAF & & & \\
- Zakat & 14.025 .385 .115 & 8.690 .496 .556 & 22.715 .881 .672 \\
- Infaq & 1.857 .107 .579 & 797.231 .224 & 2.654 .338 .803 \\
Kemanusiaan & 1.178 .274 .792 & 650.338 .575 & 1.828 .613 .367 \\
Jumlah & 47.455 .711 & 112.039 .031 & 159.494 .742 \\
\hline
\end{tabular}




\begin{tabular}{|c|c|c|c|}
\hline PERTUMBUHAN ASSET & $2000-2004$ & 2005 & $2000-2005$ \\
\hline $\begin{array}{l}\text { - DANA PROGRAM NON ZISWAF } \\
\text { Program Peningkatan Kemandirian } \\
\text { EKonomi Rakyat (P2KER) } \\
\text { Program Dana Bergulir Syariah (DBS) } \\
\text {. Program Baitulmaal Wattarmwil (B.BMT) } \\
\text {. International Development Fund (IDF) } \\
\text { - Program kompensasi pengurangan subsidi } \\
\text { BBM (PKPS BBM) } \\
\text { - Investasi Perorangan } \\
\text { - Investasi Kelembagaan }\end{array}$ & $\begin{array}{r}47.247 .000 .000 \\
6.300 .000 .000 \\
1.395 .000 .000 \\
389.654 .575 \\
\\
200.000 .000 \\
3.000 .000 .000\end{array}$ & $\begin{array}{l}10.467 .577 .008 \\
43.000 .000 .000\end{array}$ & $\begin{array}{r}47.247 .000 .000 \\
16.767 .577 .008 \\
1.395 .000 .000 \\
389.654 .575 \\
43.000 .000 .000 \\
200.000 .000 \\
3.000 .000 .000\end{array}$ \\
\hline Jumlah Dana Program Non ZISWAF & 58.531 .654 .575 & 53.467 .577 .008 & 111.999 .231 .583 \\
\hline
\end{tabular}

Tabel 1. Pertumbuhan BMM sampai dengan tahun 2005

\begin{tabular}{|c|c|c|c|}
\hline PERTUMBUHAN ASSET & $2000-2004$ & 2005 & $2000-2005$ \\
\hline $\begin{array}{l}\text { JUMLAH JARINGAN (NETWORK) } \\
\text { - ZISWAF } \\
\text { - Wilayah Pengembangan Komunitas } \\
\text { - Sekolah AIternatif } \\
\text { - PROGRAM NON ZISWAF } \\
\text { - Program Peningkatan Kemandirian Ekonomi } \\
\text { Rakyat (P2KER) } \\
\text { - Program Dana Bergulir Syariah (DBS) } \\
\text { - Program B-BMT } \\
\text { - Pentasi Mikro (IDF \& Investor Perorangan) } \\
\text { - Program kona investasi kelembagaan } \\
\text { BMM (PKPS BBM) } \\
\text { - Empowering House (Rumah Pemberdayaan) } \\
\text { PENERIMA MANFAAT (SHARE HOLDER) } \\
\text { - Muzaki } \\
\text { - Mustahik Terberdayakan }\end{array}$ & $\begin{array}{c}38 \\
8 \\
\\
1.830 \text { LM3 } \\
126 \text { KJKS } \\
407 \text { BMT } \\
54 \text { BMT } \\
7\end{array}$ & $\begin{array}{c}139 \text { KJKS } \\
22 \text { BMT, } 4 \text { BPRS } \\
176 \text { KJKS } \\
19 \\
\\
5.952 \text { orang } \\
115 \text { jiwa } \\
28.509 \text { jiwa }\end{array}$ & $\begin{array}{c}47 \text { titik } \\
26 \text { unit } \\
\\
1.830 \text { LEMBAGA } \\
265 \text { LEMBAGA } \\
407 \text { LEMBAGA } \\
26 \text { LEMBAGA } \\
54 \text { LEMBAGA } \\
176 \text { LEMBAGA } \\
26 \\
\\
13.156 \text { jiwa } \\
253 \text { jiwa } \\
63.013 \text { jiwa } \\
139.357 .560 .167\end{array}$ \\
\hline
\end{tabular}

Dalam rangka pemberdayaan ekonomi umat di lingkungan masjid, Pusat Komunikasi Ekonomi Syariah (PKES) bekerjasama dengan Baitumaal muamalat mengimplementasikan program Komunitas usaha Mikro berbasis Masjid (KUM3).

Dalam pengelolaan serta pengawasan KUM3 pihak BMM menggunakan strategi partnership dimana strategi ini dapat diartikan dengan menerapkan pengelolaan yang pendamping serta penanganan langsung dari pihak BMT, masjid dan sukarelawan. Dalam pelaksanaannya pengawasan serta pengelolaan ini dilakukan oleh BMT bersama masjid dan untuk pelaporan kepada BMM dilakukan melalui e-Mustahik kemudian data yang telah masuk dalam e-Mustahik nantinya juga akan dapat diketahui oleh para muzaki yang disinii berperan sebagai pemberi dana.

\section{Strategi program KUM3}

1. Fokus pada satu sasaran yakni Mustahik yang memiliki usaha mikro.

2. Memusatkan aktivitas ekonomi dan pembinaan di area sekitar masjid.

3. Melakukan peatihan technical skill berwirausaha dan pembinaan keagamaan kepada usaha mikro. 
4. Melibatkan partisipasi komponen masyarakat dalam pelaksanaan program.

5. Melakukan replikasi program secara nasional sehingga terbentuk sebuah. kekuatan jaringan ekonomi mikro nasional.

KUM3 terdiri atas beberapa aktivitas:

1. Pembinaan mental spiritual peserta melalui kegiatan pengajian rutin mingguan.

2. Pendampingan usaha melalui kegiatan pelatihan dan pemagangan usaha mikro.

3. Pemberian modal bergulir.

\section{Cara Pengajuan Program KUM3}

Mekanisme pengajuan kepesertaan program KUM3 dapat dilakukan dengan pengajuan kesertaan melalui Kantor Cabang Bank Muamalat terdekat, atau pengajuan langsung dan tertulis ke Baitul Maal Muamalat(BMM). Seluruh pengajuan yang memenuhi kriteria administratif akan ditindaklanjuti oleh Baitul Maal dengan mengirimkan tim ke lokasi untuk melakukan serangkaian proses survey dan assessment.

\section{Persyaratan Masjid:}

1. Terdapat struktur DKM yang aktif (Ketua, Sekretaris, Bendahara, Remaja masjid).

2. Dipakai untuk pelaksanaan shalat jum'at.

3. Berada di sekitar tempat tinggal Mustahik pemilik usaha mikro.

4. Direkomendasikan Bank Muamalat dan lulus survey kelayakan.

\section{Kriteria Peserta:}

\section{Fakir}

Mereka yang memiliki harta atau usaha namun hanya mampu mencukupi 50\% atau kurang dari kebutuhan dasarnya.

Jika di rata-rata maka penghasilan per bulannya sebesar $\mathrm{Rp}$ 1.040.000,(kota) atau $\mathrm{Rp}$ 602.083,- (desa).

2. Miskin

Mereka yang memiliki harta atau usaha namun hanya mampu memenuhi 60\% hingga 90\% dari kebutuhan dasarnya. 
Jika di rata-rata maka penghasilan per bulannya di bawah $\mathrm{Rp}$ 2.080.000,(kota) atau Rp 1.204.166,- (desa).

3. Kriteria Umum

a. Mustahik calon peserta menjalankan usaha untuk memenuhi kebutuhan hidupnya.

b. Status peserta : menikah, kepala keluarga dan memiliki tanggungan.

c. Batasan umur peserta adalah 25 - 55 thn.

d. Telah berdomisili $>3$ tahun.

e. Direkomendasikan oleh DKM/Takmir/Nadzir.

Fasilitas yang didapatkan oleh peserta yaitu antara lain:

Bantuan modal usaha : Rp 750.000,-s/d Rp. 2.000.000,-

Investasi sarana usaha : sampai dengan $\mathrm{Rp} 1.000 .000,-/$ orang.

Sedangkan hak dan kewajiban peserta adalah sebagai berikut :

1. Mendapat modal usaha \& bimbingan

2. Menghidupkan masjid

3. Shubuh \& Isya' berjamaah

4. Taklim pekanan

5. Mengikuti program

6. Tertib angsuran \& tabungan

7. Musyawarah rutin

8. Kriteria Pendamping

9. Jamaah aktif masjid yang berdomisili minimal 3 tahun

10. Menguasai komputer \& internet

11. Direkomendasikan oleh DKM

12. Mempunyai integritas dan reputasi yang baik

13. Pendidikan terakhir minimal SLTA, diutamakan S1 dan atau D3

14. Diutamakan yang pernah mengikuti program pendamping

15. Berjiwa Pemberdayaan (punya keinginan kuat untuk mengembangkan masyarakat)

16. Memiliki kemampuan baca quran dan tabligh

17. Usia min 25 th dan maks. 45 th

18. Tidak bekerja di lembaga formal (pegawai negri / swasta) 


\section{Implementasi Pendistribusian Dana Zakat Infaq}

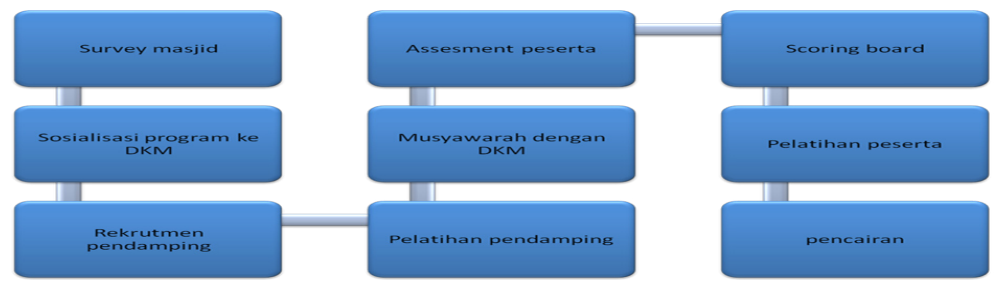

Gambar 1. Tahap dalam program KUM3 (Sumber: BMM, 2009)

Adapun tahapan-tahapan dalam program KUM3 ini adalah sebagai berikut:

1. Survey wilayah

2. Survey masjid

3. Sosialisasi program ke DKM dan MOU

4. Rekruitmen Pendamping

5. Pelatihan Pendamping

6. Musyawarah dengan DKM untuk merekomendasikan calon peserta

7. Assesement Peserta

8. Scoring board

9. Pelatihan Peserta

10. Penandatangan $\mathrm{MOU}$

11. Pencarian dana KUM3

Tahapan dan Schedule program KUM3:

Pengguliran Tahap 1: 4 Bulan (1 Bln grass period, 3 Bln angsuran)

Pengguliran Tahap 2: 4 Bulan (1 Bln grass period, 3 Bln angsuran)

Pengguliran Tahap 3: 4 Bulan (1 Bln grass period, 3 Bln angsuran)

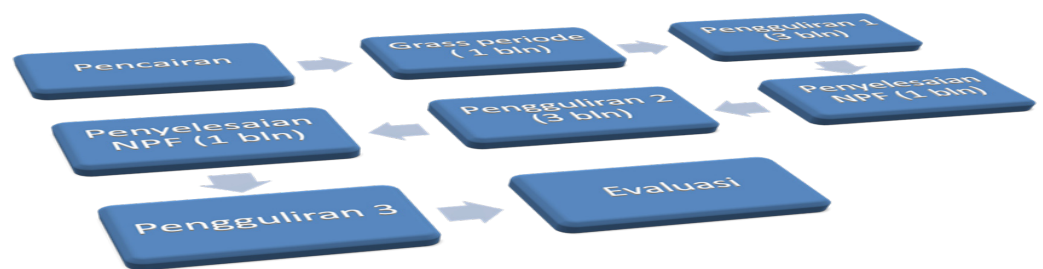

Gambar 2. Fase pengguliran dana (Sumber: BMM, 2009)

\section{Manajemen Program KUM3}

Dalam pelaksanaan program kum 3 terdapat 3 model pembiyaan yakni: 


\section{Model Aqh}

Dalam model ini pembiyaan diberikan sebesar 750.000 - 2 jt. Pembiyaan model ini dilakukan pada tahun 1 berjalan. Dalam model ini memliki tujuan berupa terciptanya kesolidan antara pendamping dan peserta, pendamping difokuskan pada pembangunan kesalihan peserta, terlaksanannya target ibadah $60 \%$, kelancaran pengembalian sesuai jadwal.

2. Model Qardh

Dalam model ini pembiyaan diberikan sebesar 2.5 jt- 5 jt. Pembiyaan model ini dilakukan pada tahun ke-2 berjalan. Dalam model ini memliki tujuan berupa peningkatan kualitas pendamping, pendamping difokuskan pada analisa dan pengembangan usaha peserta, terlaksanannya target ibadah $80 \%$, serta bertambahnya kapasitas usaha peserta.

\section{Model musyarakah}

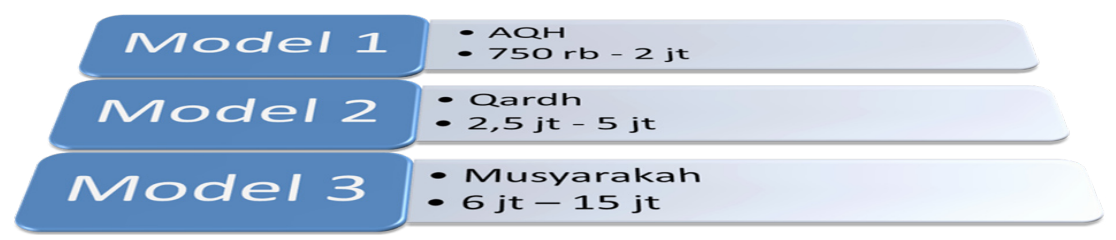

Gambar 3. Model pembiayaan (BMM, 2009)

Dalam model ini pembiyaan diberikan sebesar 6 jt - 15 jt. Pembiyaan model ini dilakukan pada tahun ke-3 berjalan. Dalam model ini memliki tujuan berupa peningkatan peran pendamping, pendamping difokuskan pada supervisi usaha peserta, terlaksanannya target ibadah $100 \%$, serta bertambahanya skala usaha peserta.

Tabel 2. Time frame pengguliran program (Sumber: BMM, 2009)

\begin{tabular}{|l|l|l|}
\hline TAHUN 1 & TAHUN 2 & TAHUN 3 \\
\hline AQH & Qardh & Musyarakah \\
\hline $\begin{array}{l}\text { Solid pendamping dan } \\
\text { peserta }\end{array}$ & $\begin{array}{l}\text { Peningkatan kualitas } \\
\text { pendamping }\end{array}$ & $\begin{array}{l}\text { Peningkatan peran } \\
\text { pendamping }\end{array}$ \\
\hline $\begin{array}{l}\text { Pendamping fokus pada } \\
\text { pembangunan kesalihan } \\
\text { peserta }\end{array}$ & $\begin{array}{l}\text { Pendamping fokus pada } \\
\text { analisa dan pengembangan } \\
\text { usaha peserta }\end{array}$ & $\begin{array}{l}\text { Pendamping fokus pada } \\
\text { superfisi usaha }\end{array}$ \\
\hline
\end{tabular}




\section{Implementasi Pendistribusian Dana Zakat Infaq}

\begin{tabular}{|l|l|l|}
\hline $\begin{array}{l}\text { Terlaksana target ibadah } \\
60 \%\end{array}$ & Terlaksana ibadah 80\% & Terlaksana ibadah 100\% \\
\hline $\begin{array}{l}\text { Lancar pengembalian } \\
\text { sesuai jadual }\end{array}$ & $\begin{array}{l}\text { Bertambah kapasitas usaha } \\
\text { peserta }\end{array}$ & $\begin{array}{l}\text { Bartambah skala usaha } \\
\text { peserta }\end{array}$ \\
\hline
\end{tabular}

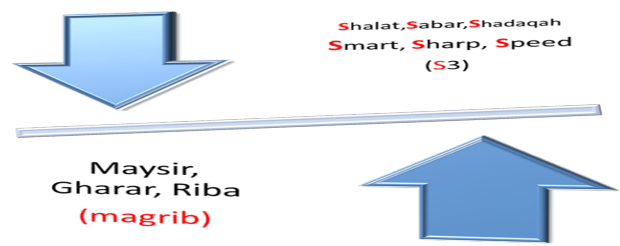

Gambar 4. Spirit kurikulum (BMM, 2009)

Sebagai alat untuk menuju tujuan program kum3 ini terdapat kurikulum yang digunakan dalam pelaksanaan program ini. Terdapat 3 model kurikulum yang diberikan yakni:

\section{Kurikulum pendampingan 1}

Tabel 3. Kurikulum pendampingan 1 (Sumber: BMM, 2009)

\begin{tabular}{|l|l|}
\hline KURIKULUM AGAMA & KURIKULUM USAHA \\
\hline $\begin{array}{l}\text { Membangun pemahaman aqidah dan } \\
\text { tauhid peserta }\end{array}$ & $\begin{array}{l}\text { Memastikan peserta mengembalikan } \\
\text { AQH }\end{array}$ \\
\hline $\begin{array}{l}\text { Membangun pemahaman peserta } \\
\text { tentang Islam }\end{array}$ & $\begin{array}{l}\text { Mengawal penggunaan dana oleh } \\
\text { peserta }\end{array}$ \\
\hline $\begin{array}{l}\text { Membangun semangat peserta dalam } \\
\text { beribadah (berjamaah, amalan sunnah, } \\
\text { tilawah, dll.) }\end{array}$ & $\begin{array}{l}\text { Mematuhi perkembangan bisnis } \\
\text { peserta }\end{array}$ \\
\hline $\begin{array}{l}\text { Membangun keyakinan peserta bahwa } \\
\text { Allah SWT penentu rizki }\end{array}$ & $\begin{array}{l}\text { Mendorong peserta untuk memiliki } \\
\text { tabungan sebagai modal investasi }\end{array}$ \\
\hline $\begin{array}{l}\text { Menanamkan prinsip-prinsip amanah, } \\
\text { istiiqomah, mujahadah, sabar dan } \\
\text { sedekah }\end{array}$ & \\
\hline
\end{tabular}

\section{Kurikulum pendampingan 2}

Tabel 4. Kurikulum pendampingan II (Sumber: BMM, 2009)

\begin{tabular}{|l|l|}
\hline KURIKULUM AGAMA & KURIKULUM USAHA \\
\hline $\begin{array}{l}\text { Membiasakan peserta melaksanakan } \\
\text { ibadah dawn amalan-amalan yang } \\
\text { mendatangkan keberkahan dan } \\
\text { keridhoan Allah }\end{array}$ & $\begin{array}{l}\text { Menetapkan peserta yang berhak } \\
\text { mengikuti KUM model 2 }\end{array}$ \\
\hline
\end{tabular}




\begin{tabular}{|l|l|}
\hline $\begin{array}{l}\text { Mendorong peserta meningkatkan } \\
\text { kepeduliannya (ZIS) }\end{array}$ & $\begin{array}{l}\text { Menggulirkan kembali AQH kepada } \\
\text { peserta yang masih dianggap layak }\end{array}$ \\
\hline & $\begin{array}{l}\text { Merekrut peserta dari daftar } \\
\text { waiting list untuk menggantikan } \\
\text { peserta yang lulus le model 2 atau } \\
\text { terdiskualifikasi }\end{array}$ \\
$\begin{array}{l}\text { Membangun pemahaman peserta } \\
\text { terhadap prinsip-prinsip ekonomi Islam } \\
\text { dan akad jual beli }\end{array}$ & $\begin{array}{l}\text { Melerage usaha peserta KUM } \\
\text { model 2 } \\
\text { Mempersiapkan KUM model 2 agar } \\
\text { siap memasuki KUM model 3 }\end{array}$ \\
\hline
\end{tabular}

\section{Kurikulum pendampingan 3}

Tabel 5. Kurikulum pendampingan III (Sumber: BMM, 2009)

\begin{tabular}{|l|l|}
\hline KURIKULUM AGAMA & KURIKULUM USAHA \\
\hline $\begin{array}{l}\text { Mendorong peserta meningkatkan } \\
\text { intensitas pelaksanaan ibadah dan } \\
\text { amalan-amalan sunnah }\end{array}$ & $\begin{array}{l}\text { Menetapkan peserta KUM model 2 } \\
\text { yang berhak mengikuti KUM model } \\
3\end{array}$ \\
\hline $\begin{array}{l}\text { Mendorong peserta meningkatkan } \\
\text { kepeduliannya (ZIS) }\end{array}$ & $\begin{array}{l}\text { Melaksanakan proses 2 yang } \\
\text { berlangsung di tahun dua dan tiga }\end{array}$ \\
\hline $\begin{array}{l}\text { Membangun pemahaman peserta } \\
\text { terhadap prinsip-prinsip ekonomi Islam } \\
\text { dan akad jual beli }\end{array}$ & $\begin{array}{l}\text { Mempersiapkan proses hand over } \\
\text { program AQH kepada masjid dan } \\
\text { peserta }\end{array}$ \\
\hline
\end{tabular}

Tabel 6. Parameter keberhasilan pendampingan (Sumber: BMM, 2009)

\begin{tabular}{|l|l|l|}
\hline No & Parameter & Indikator \\
\hline 1 & Ruhiyah peserta & $\begin{array}{l}\text { Salimul Aqidah } \\
\text { Sosihul Ibadah } \\
\text { Matinul Khuluk }\end{array}$ \\
\hline 2 & Partisipasi peserta & $\begin{array}{l}\text { Pertemuan mingguan } \\
\text { Pengajaran } \\
\text { Pelatihan }\end{array}$ \\
\hline 3 & Usaha peserta & $\begin{array}{l}\text { Peningkatan keuntungan } \\
\text { Kerapian administrasi keuangan } \\
\text { Perluasan pasar } \\
\text { Inovasi produk }\end{array}$ \\
\hline
\end{tabular}

Dalam memonitoring kegiatan peserta maka peserta diberi form atau kartu kegiatan yang berbentuk sebagai berikut: 
Tabel 7. Fom monitoring peserta (Sumber: BMM, 2009)

\begin{tabular}{|c|c|c|c|c|c|c|c|}
\hline Bul & & Minggu & Nama $A$ & Anggota & & & Total \\
\hline No & Aktivitas & Target/Minggu & \begin{tabular}{l|l|l}
$\mathrm{A}$ & $\mathrm{B}$ \\
\end{tabular} & \begin{tabular}{l|l|l|} 
C & D & E \\
\end{tabular} & \begin{tabular}{l|l|} 
& $F$ \\
\end{tabular} & G & $\%$ \\
\hline 1 & Kehadiran & 1 kali & & & & & \\
\hline 2 & Musyawarah & 21 kali & & & & & \\
\hline 3 & $\begin{array}{l}\text { Shalat jama'ah } \\
\text { di masjid }\end{array}$ & 7 kali & & & & & \\
\hline 4 & Qiyamullail & 1 kali & & & & & \\
\hline 5 & Menabung & 7 kali & & & & & \\
\hline 6 & Silaturrahim & 2 kali & & & & & \\
\hline 7 & $\begin{array}{l}\text { Me m b a n t u } \\
\text { Istri }\end{array}$ & 1 kali & & & & & \\
\hline 8 & $\begin{array}{l}\text { Membaca al } \\
\text { Quran }\end{array}$ & 21 halaman & & & & & \\
\hline 9 & Al Ma'surat & 7 kali & & & & & \\
\hline
\end{tabular}

Parameter untuk mengukur tingkat keberhasilan pemberdayaan tersebut bisa dilihat dari tingkat perkembangan usaha yang dilakukan setelah mendapatkan tambahan dana pemberdayaan tersebut. Sistem pembiayaan yang dikembangkan oleh BMT dalam pendistribusian dan pengelolaan dana KUM3 untuk pemberdayaan UKM ini sebenarnya sangat bagus sekali. Dana KUM3 yang ditujukan pada masyarakat khususnya bagi masyarakat yang mempunyai usaha dan yang aktif datang ke masjid setempat ini, sangat membantu sekali bagi usahanya.

Biasanya pada pertemuan tersebut tidak hanya membahas tentang pengembalian dana yang telah dikucurkan. Melihat dari tujuan utamanya adalah memberdayakan ekonomi mustahik dengan menitikberatkan aktivitas pembangunan iman dan taqwa mustahik, maka pada pertemuan tersebut diadakan pula shalat berjama'ah, pengajian serta kultum yang diadakan oleh pengurus setempat. Setiap pertemuan, selain diadakan pengembalian dan acara rutin, diadakan pula adanya tabungan dan infak. Jadi, para mustahik selain dapat mengembalikan dana tersebut, mustahik juga mendapatkan tabungan yang dapat diambil sewaktu-waktu disaat membutuhkan serta pahala karena berinfak. Dalam satu periode putaran biasanya terjadi 10 kali angsuran dana mustahik. Apabila terjadi kemacetan dana, maka pada putaran yang selanjutnya dapat digantikan oleh mustahik lain yang bersedia mengganti. 


\section{Bank Syariah Mandiri}

Pengelolaan dana ZIS Bank Syariah Mandiri oleh LAZNAS BSM Umat yang merupakan lembaga amil zakat yang lahir dari sebuah kesadaran yang tulus untuk meningkatkan kepedulian sosial dan merringankan penderitaan saudara sesama. Berangkat dari kenyataan adanya peningkatan jumlah rakyat miskin terutama sejak krisis ekonomi yang menyebabkan jutaan orang kesulitan mencari lapangan pekerjaan, semakin tidak jelasnya nasib pengungsi si ratusan titik di seluruh Indonesia akibat dari konflik sosial yang tidak berkesudahan. Ketika kebutuhan dasar mereka sulit terpenuhi, ketika jutaan anak-anak kini putus dari bangku sekolah dan semakin tidak adanya perhatian kepada janda dan kaum jompo, maka LAZNAS BSM Umat mengajak kepada seluruh masyarakat menyisihkan harta mereka untuk dioptimalkan dan dilipatgandakan pemanfaatannya dalam program pemberdayaan dan pendayagunaan, menciptakan lapangan kerja baru, menguatkan usaha kecil, mendidik anak-anak bangsa yang tidak mampu melalui beasiswa, pemberian santunan bagi kaum miskin dan terlantar.

LAZNAS BSM Umat adalah sebuah lembaga nirlaba resmi yang eksistensinya diakui sejak 17 September 2002, melalui SK Menteri Agama RI No 406 Tahun 2002, untuk memudahkan dan memfasilitasi kebutuhan masyarakat muzaki dalam menyalurkan dananya kepada mereka yang membutuhkan dengan jaringan yang tepat serta berdayaguna. LAZNAS BSM Umat didukung oleh sistem perbankan syariah dan orang-orang yang profesional di bidangnya. Dengan struktur organisasi sebagai berikut:

1. Dana ZIS tersebut digulirkan dalam bentuk perjanjian pembiayaan tanpa imbalan dengan kewajiban pihak peminjam mengembalikan pokok pinjaman secara sekaligus atau cicilan dalam jangka waktu tertentu. LAZNAS BSM Umat mendistribusikan dan ZIS tersebut kepada LAZIS Sabilillah. Pendistribusian dana ZIS tersebut kepada UKM dengan tanpa membebankan imbalan atau bunga, akan tetapi untuk biaya administrasi dan pembukaan tabungan pokok sebesar Rp. 75.000 dibebankan kepada para UKM tersebut Dalam pendistribusian dana ZIS tersebut LAZIS Sabilillah melakukan pendampingan terhadap para UKM. Pendampingan ini dilakukan dengan cara mengontrol pemberian dana yang dialirkan serta pelaksanaan survey ketika akan mendistribusikan dana zakat. Pemberdayaan UKM dengan dana ZIS ini diharapkan akan dapat memperbaiki perekonomian masyarakat, khususnya masyarakat kecil dalam mencapai hidup yang 
lebih baik lewat usaha yang mereka tekuni. Mereka diharapkan agar tidak selalu tergantung atau meminta pada orang, namun mereka diharapkan suatu saat juga akan dapat menjadi muzakki memberi kepada orang lain dari hasil kerja kerasnya.

2. Dana ZIS yang digulirkan oleh LAZIS Sabilillah dimulai sejak tahun 2006. Rata-rata jumlah dana yang digulirkan kepada setiap orang adalah Rp.1.000.000 sampai dengan Rp. 2.000.000. Jumlah dana yang digulirkan oleh masing-masing UKM tergantung dari proses survey yang dilakukan oleh pihak LAZIS Sabilillah dengan pertimbangan syarat-syarat yang diajukan.

Pengalokasian dana ZIS BSM umat diperuntukkan untuk program sebagai berikut:

a. Program santunan

Program ini merupakan penyaluran dana ZIS tanpa ada target-target perubahan atas keadaan dan kondisi mustahik, kecuali hanya sekedar meringankan beban kehidupan bagi mustahik. Program santuan ini terdiri dari :

b. Santunan beasiswa

Merupakan penyaluran dan ZIS yang diperuntukkan kepada anak yatimpiatu serta du'afa non panti yang diangkat sebagai anak asuh lembaga untuk membiayai biaya pendidikan sekolah (SPP).

c. Santunan penunjang belajar (SPB)

Merupakan penyaluran dan ZIS yang diperuntukkan kepada anak yatim-piatu serta du'afa non panti yang diangkat sebagai anak asuh lembaga untuk membiayai biaya keperluan sarana penunjang pendidikan (buku, alat tulis, seragam, sepatu, buku paket).

d. Santuanan lansia

Merupakan penyaluran dana ZIS kepada fakir miskin yang lanjut usia. e. Santunan Gharim

Merupakan penyaluran dan ZIS kepada keluarga miskin yang mempunyai banyak hutang gun mencukupi kebutuhan sehari-hari.

f. Santuanan Musafir

Merupakan penyaluran dana ZIS kepada orang yang terlantar atau sedang bepergian atau dalam perjalanan untuk kepentingan ibadah kepada Allah. Tak kurang dari 250-an orang musafir yang telah mendapatkan bantuan selama kurun wak tu 1 tahun terakhir.

g. Santunan Sosial

Merupakan penyaluran dana ZIS kepada keluarga miskin untuk keperluan 
makanan, pengobatan, kematian, dll.

h. Santunan Guru Ngaji

Merupakan penyaluran ZIS kepada Guru-guru ngaji di TPQ

i. Program Pemberdayaan

Adalah merupakan program penyaluran dana ZIS kepada Mustahik dengan disertai target-target perubahan atas keadaan atau kondisi Mustahik untuk menjadi lebih baik dari keadaan atau kondisi sebelum adanya penyaluran. j. Program Bina Prestasi

Adalah penyaluran dana ZIS kepada mustahik melalui pola pembinaan anak asuh dengan cara memberikan bimbingan les privat langsung maupun sinergi dengan bimbingan les privat lokal. Program ini dilaksanakan dengan target anak asuh lembaga yang berada di tingkat/kelas 6 yang akan menghadapi ujian akhir nasional, yang diharapkan dapat menunjang nilai-nilai UAN agar mencapai standar nasional.

k. Program Siswa Mandiri

Merupakan penyaluran dana ZIS kepada mustahik melalui pola pembinaan kemandirian siswa dengan cara memberikan bantuan berupa sepeda kepada anak asu untuk keperluan transportasi menuju sekolah, guna melatih kemandirian siswa dan meringankan beban biaya transportasi sekolah bagi keluarga miskin.

1. Program Pendampingan Peingkatan Mutu TPQ (LP2M-TPQ)

Adalah penyaluran dana ZIS kepada mustahik melalui pola pendampingan dan pembinaan kepada guru-guru ngaji untuk meningkatkan kualitas guru ngaji, sehingga secara langsung akan meningkatkan kualitas dan mutu TPQ dalam pengelolaan TPA.

m. Program Peningkatan Minat Baca

Adalah penyaluran dana ZIS kepada mustahik melalui pola pengenalan Perpustakaan sebagai sumber ilmu pengetahuan kepada siswa binaan dan santri-santri TPQ, dengan cara mendatangkan atau mendatangi siswa/santri TPQ untuk mengenalkan buku-buku Perpusakaan, sehingga dapat mendorong dan meningkatkan kemampuan membaca bagi anak asuh dan santri TPQ.

n. Program tabungan siswa

Adalah penyaluran dana ZIS kepada mustahik melalui pola tabungan siswa dengan cara mengambil sebagian dari dana ZIS yang telah disalurkan kepada siswa untuk ditabungkan di Lembaga Pembiayaan Masjid Sabilillah sebagai saham/tabungan jangka panjang yang akan diambil/diberikan setelah akhir masa pendidikan beserta beserta bagi hasil tabungan yang diperoleh 
selama menabung. Data penerima sesuai dengan data anak asuh penerima santuna beasiswa.

o. Program Pemberdayaan Tukang Becak

Adalah penyaluran dana ZIS kepada mustahik melalui pola penyaluran dana bergulir dengan cara membelikan sebuah becak kepada tukang becak setoran (bukan becak sendiri) untuk diangsur pembeliannya sesuai setoran harian yang biasa di lakukan, sampai lunas. Maka becak akan menjadi milik sendiri sehingga akan meningkatkan kesejahteraan bagi keluarga Tukang becak.

p. Program Pembinaan Musholla

Adalah penyaluran dana ZIS kepada musholla untuk biaya operasional musholla (listrik/air) guna meringankan beban musholla serta membangun forum komunikasi antar Musholla sehingga meningkatkan sumber daya manusia dan pengelolaan musholla.

\section{Pendistribusian ZIS untuk Pembiayaan UKM}

Salah satu bank syariah di 'Malang yang telah berhasil mendistribusikan dana ZIS adalah Bank Syariah Mandiri (BSM). Adapun tujuan dari bank syariah mandiri dalam penyaluran dana ZIS adalah mewujudkan perekonomian Indonesia melalui pemberdayaan UKM. Terutama bagi masyarakat kecil yang ingin mendirikan usaha untuk menambah pendapatannya. Dengan alasan tersebut para perbankan syariah mendistribusikan dananya untuk mengembangkan potensi dengan menggunakan pemanfaatan dana Qordul Hasan untuk pemberdayaan umat. Dalam pengelolaannya BSM tidak mengelola secara langsung, tetapi diserahkan untuk di Malang kepada Lembaga Pendidikan dibawah naungan Masjid Sabilillah Blimbing Malang. Adapun alasan BSM untuk tidak mengelola secara langsung adalah untuk menghindari resiko, karena keterbatasan jenis usaha dan aset yang dimiliki oleh kelompok usaha tersebut. Atau karena kurangnya jaminan untuk bisa dijadikan bukti bahwa mereka benar-benar membutuhkan pinjaman. Dana yang pertama kali diterima oleh Masjid Sabilillah adalah sebesar Rp 100.000.000 (seratus juta rupiah). Kemudian dana tersebut dikelola oleh Koperasi atau BMT yang dimiliki Masjid Sabilillah untuk UKM.

\section{Tempat pengelolaan ZIS Masjid Sabilillah}

Dalam pengelolaan ZIS, LAZIS Masjid Sabilillah bekerja sama dengan BMT Masjid Sabilillah,selanjutnya dikelola oleh BMT Masjid Sabilillah. Dana 
itu diberikan kepada peserta yang ingin mendirikan usaha kecil misalkan, usaha bakso, penjualan pulsa, penjualan sayur, dll. Untuk mendapatkan dana pinjaman tersebut Masjid Sabilillah mempunyai kriteria peserta yang bagaimana yang berhak mendapatkan pinjaman tersebut. Khususnya masyarakat yang kurang mampu. Untuk mengetahui keadaan dari peserta masjid Sabilillah harus menanyakan beberapa hal yang menyangkut keadaan penserta atau data-data yang mendukung bagi peserta penerima dana ZIS. Syarat-syarat peserta yang ingin menjadi anggota BMT Sabilillah:

1. Pendapatan kurang dari $\mathrm{Rp} 500.000$ / bulan

2. Jumlah anak yang ditanggung minimal 3 anak

3. Kendaraan yang dimilki dengan proses kredit

4. Keterangan dari Rt dan Rw

5. Keadaan rumah

6. Jarak tempat kerja dengan rumah

7. Menggunakan sumur atau PDAM, dll

Selain syarat-syarat diatas para peserta harus memenuhi persyaratan selanjutnya, yaitu

Simpanan pokok $\quad \mathrm{Rp} 50.000$

Administrasi $\quad \mathrm{Rp} 20.000$

Simpanan wajib $\quad \underline{R p 5.000+}$

Rp 75.000

Sistem yang dilakukan dalam mendistribusikan dana ZIS yang dilakukan oleh masjid Sabilillah adalah tidak terlalu memberatkan bagi peserta. Dari pihak peserta melaporkan usaha apa yang akan didirikan dengan alasan-alasan yang bisa diterima dan data-data yang mendukung untuk peserta sehingga bisa mendapatkan dana ZIS. Setelah berkas sudah diterima kemudian dana bisa dicairkan, dari pihak Masjid Sabilillah meminta jaminan yang bisa diberikan oleh peserta misalkan STNK atau kalau tidak ada bisa barang-barang yang pantas untuk dijadikan jaminan, bahkan dari hasil wawancara kami misalkan adanya hanya surat nikah maka itu bisa dijadikan jaminan. Syarat-syarat bagi peserta yang meminjam diatas 1 juta:

1. $\quad \mathrm{KTP}$ (Kartu tanda penduduk)

2. $\mathrm{KK}$ (kartu keluarga)

3. Jaminan, misalkan BPKB, Surat Nikah, Akte kelahiran, Ijazah.

Setelah dana dicairkan, mereka wajib membayar hutang dengan cara mingguan atau bulanan. Apabila dalam waktu jatuh tempo peserta tidak bisa melunasinya maka BMT atau Masjid Sabilillah akan memberikan peringatan. 
Tindakan yang dilakukan jika peserta tidak membayar pada saat jatuh tempo, diantaranya adalah:

1. Diinformasikan kepada peserta melalui telpon

2. Petugas mendatangi kerumah peserta

3. Diinformasikan melalui surat peringatan

4. Meningkatkan kinerja LAZIS Masjid Sabilillah

Untuk meningkatkan kinerja dari pendistribusian ZIS, Masjid Sabilillah melalukan pendampingan bagi para peserta UKM atau peserta, dalam satu bulan melakukan pelatihan dua kali yaitu pada hari Minggu, untuk semua peserta diwajibkan mengikuti pelatihan tersebut.

\section{BNI Syariah}

Dana qardhul hasan di BNI dikelola oleh LAZ BAMUIS BNI yang merapakan sumber dana dari zakat, infaq, sadaqah dan sejenisnya dari para nasabah, para pegawai, para pensiunan, para pegawai di lingkungan anak perusahaan dan lainnya. Qardhul hasan merapakan salah satu produk yang dikembangkan oleh bank-bank syariah termasuk di BNI Syariah Cabang Malang. Produk Qardhul hasan atau disebut dengan Dana Kebajikan adalah memberikan pembiayaan tanpa ada tambahan atau hanya kembali pokok. Adapun dana yang terkumpul adalah dari dana zakat, infaq dan sodaqoh (ZIS) dan sejenisnya. BNI Syariah Cabang Malang yang didirikan pada tanggal 29 April 2000 merupakan bank yang beroperasi berdasarkan prinsip syariah pertama kali yang ada di Malang juga sudah memulai untuk mengembangkan produk qardul hasan. Dana yang digunakan untuk pengembangan produk qardul hasan berasal dari dua sumber yaitu:

\section{Pemotongan Gaji Pegawai}

Kegiatan mobilisasi dana yang selama ini dilakukan oleh BNI Syariah Cabang Malang adalah dari para pegawai yang dipotong 2,5\% tiap bulan langsung dari gaji brutonya oleh bagian atau seksi yang mengurus masalah kepegawaian. Pemotongan tersebut dikenakan pada semua pegawai kecuali pegawai non administrasi. Hasil pemotongan tersebut kemudian dibagai dua yaitu separoh untuk disetorkan ke BAMUIS BNI Pusat dan separohnya lagi untuk dikelola sendiri.

\section{Hibah dari BAMUIS BNI}

Dengan berdirinya BNI Syariah Cabang Malang kemudian BAMUIS BNI Pusat mengucurkan dana pada lembaga tersebut. Dana itu berupa hibah yang harus dikelola sendiri dan dipergunakan untuk pengembangan produk qardul hasan. 


\section{Penyaluran Dana Qardhul hasan}

Dana yang didistribusikan oleh BNI Syariah Cabang Malang adalah kucuran dana dari BAMUIS BNI Pusat. Ada dua kelompok bentuk penyalurannya sesuai dengan sumber dana yang diterima. Bentuk pertama yaitu dana yang dihibahkan dari BAMUIS BNI Pusat yang diterima pada awal pendirian BNI Syariah Malang. Dana tersebut dikelola dan disalurkan sebagai dana qardhul hasan yang produktif. Sedangkan kelompok kedua yaitu dana yang berasal dari pemotongan gaji pegawai kemudian disalurkan langsung atau tunai (carity). Karena disalurkan bentuk tunai yaitu bagi habis maka dana tersebut tidak mengharapkan kembaliannya. Dana ini dipergunakan dalam bentuk produktif dan konsumtif. Penyaluran dana yang diberikan adalah untuk pemberdayaan ekonomi umat dengan cara memberikan bantuan pemodalan bagi usaha kecil baik itu berbentuk hibah/tunai maupun dengan dana bergulir. Penyaluran dana qardhul hasan disamping diberikan untuk penambahan modal usaha atau mengawali usaha juga untuk kegiatan kemanusiaan seperti rnemberi santunan pada yatirn piatu, bantuan hidup pada fakir miskin serta memberi bantuan untuk perbaikan atau renovasi sarana ibadah maupun sosial.

\section{Program Pemberdayaan Ekonomi dengan Dana Qardhul hasan}

Konsep pemberdayaan umat yang dimaksud di sini berkait dengan pendayagunaan dana qardhul hasan. Pendayagunaan dana qardhul hasan adalah bentuk pemanfaatan sumber daya (dana zakat, infaq dan sodaqah) secara maksimum sehingga berdayaguna untuk mencapai kemaslahatan bagi umat. Pendayagunaan dana diarahkan pada tujuan pemberdayaan melalui berbagai program yang berdampak positif (maslahat) bagi masyarakat khususnya umat Islam yang kurang beruntung (golongan asnaf). Dengan pemberdayaan ini diharapkan akan tercipta pemahaman dan kesadaran serta membentuk sikap dan perilaku hidup individu dan kelompok menuju kemandirian. Dengan demikian, pemberdayaan adalah upaya memperkuat posisi sosial dan ekonomi dengan tujuan mencapai penguatan kemampuan umat melalui dana bantuan yang pada umumnya berupa kredit untuk usaha produktif sehingga mustahiq sanggup meningkatkan pendapatannya dan juga membayar kewajibannya (zakat) dari hasil usahanya atas kredit yang dipinjamnya.

Selama ini kegiatan pendayagunaan dana qardhul hasan yang dilakukan oleh BNI Syariah Malang yang diteliti ini mencakup kegiatan jangka panjang dan jangka pendek di bidang produksi, konsumsi maupun program sosial kemasyarakatan. Sementara itu, pendayagunaan dana qardhul hasan untuk tujuan 
usaha-usaha produktif tampaknya lebih dititikberatkan pada satu titik pusat pemberdayaan melalui program : pembiayaan usaha produktif. Dalam skala lebih luas, dana tersebut disalurkan juga pada program-program yang bersifat sosialkonsumtif.

Dari keseluruhan program pemberdayaan tersebut dapat diurut program yang paling mendesak, yaitu bantuan biaya hidup untuk memenuhi pokok rutin dan insidental, dan yang kurang mendesak adalah kebutuhan bantuan kemanusiaan dan bantuan pembangunan/renovasi sarana ibadah dan sosial.. Berdasarkan program pemberdayaan, dapat diketahui bahwa tampaknya BNI Syariah Malang menetapkan skala prioritas yang lebih berat pada bantuan ekonomi produktif dalam bentuk pemodalan dan pembinaan usaha. Program pemberdayaan seperti ini memang besar manfaatnya karena dengan program semacam ini akan bisa mentransfer mustahiq menjadi muzakki. Namun, sayangnya tidak seluruh program pemberdayaan ekonomi produktif ini berhasil. Tidak sedikit yang gagal karena proyek-proyek bantuan tersebut dilaksanakan tanpa didahului survei juga dukungan data dan informasi akurat, serta tanpa dukungan kemampuan pengelolaan dan ketersediaan dana yang memadai. Pengalokasian dana qardhul hasan yang lebih menitikberatkan program pemodalan usaha produktif ini juga memiliki sisi kelemahannya. Kelemahan tersebut berupa kian lamanya penderitaan yang dialami kaum dhuafa yang lebih memerlukan bantuan untuk memenuhi kebutuhan pokok rutinnya. Lagi pula, dana qardul hasan yang merupakan dana dari kumpulan zakat, infaq dan sadaqoh memang sebaiknya digunakan dengan melihat desakan kebutuhan pokok sehari-hari kaum dhuafa.

Penyaluran dana tunai selama ini ditujukan kepada muallaf, ghorimin, fakir, miskin tetapi porsi dana tunai lebih sedikit dibandingkan dengan dana untuk membiayai program-program pemberdayaan yang banyak berkait dengan program sosial dan kemanusiaan, pemodalan usaha produktif, pembangunan sarana ibadah, santunan kesehatan, dan sebagainya. Selebihnya masih terdapat dana tertahan yang belum tersalurkan. (periksa Tabel Perolehan dan Penyaluran Dana Qardul Hasan).

Hal ini sesuai dengan pendapat sejumlah ahli hukum Islam bahwa qardul hasan (dari zakat) dapat digunakan sebagai alat countercyclical dengan tidak mendistribusikan seluruh dana tersebut pada periode boom, sebagian dana tersebut dialokasikan sebagai dana berjaga-jaga agar dapat dipergunakan pada masa resesi (Chapra, 2001: 333-334). Kebijakan program pemberdayaan yang diterapkan memang tidak salah, mengingat semangat yang ditanamkan oleh Islam 
kepada umatnya melalui ajaran tentang zakat, yaitu semangat untuk berusaha dan memperbaiki kehidupan menuju taraf hidup yang lebih baik atau dapat diimplikasikan dalam kalimat: mengubah ketergantungan menjadi kemandirian, atau mengubah hidup kekurangan menjadi berkecukupan, atau pun mengubah mustahiq menjadi muzakki melalui multi manfaat zakat.

Dalam konteks inilah, di antara sebagian ulama dan ahli hukum Islam ada yang kurang setuju dengan pemanfaatan dana zakat untuk berbagai program pemberdayaan. Karena, berdasar sunnah nabi dana zakat itu harus disegerakan dibagikan ke mustahiq, apalagi jika masih terdapat umat yang sehari-harinya tidak sanggup memenuhi kebutuhan pokok rutinnya (fakir). Keadaan ini tidak mungkin dapat diatasi jika lembaga pengelola dana qardhul hasan (yang bersumber dari zakat infaq dan sadaqoh) tidak memiliki data kemiskinan umat. Agar zakat dapat memainkan peranan secara berarti, sejumlah ulama dan ahli hukum Islam menyarankan bahwa zakat seharusnya menjadi suplemen pendapatan permanen yang utamanya diperuntukkan bagi asnaf fakir dan bila masih ada sisa dana baru diperuntukkan untuk asnaf miskin yang punya kemauan untuk meningkatkan pendapatannya. Dalam tataran lebih luas lagi, zakat dapat digunakan untuk menyediakan pelatihan keterampilan dan penyediaan modal "unggulan" agar kaum dhuafa dapat menjalankan usaha kecil sehingga pada akhirnya mereka dapat berusaha secara mandiri.

Pendayagunaan dana qardhul hasan untuk tujuan mengadakan dan mengembangkan usaha produktif kaum dhuafa memang tidak bertentangan dengan ajaran Islam. Berdasarkan mazhab Syafi'i bahwa pemenuhan kebutuhan fakir dan miskin dengan dana zakat dapat dilakukan sampai batas mereka tidak hidup terlantar. Ini berarti penyaluran dana zakat harus diprioritaskan bagi kaum terlantar, dan sesudah itu untuk usaha-usaha yang dapat mengangkat taraf hidup mereka. Ini pula yang dijadikan sebagai dasar bahwa dana zakat yang dialokasikan untuk program bantuan sarana produktif guna meningkatkan kemampuan produksi dan membuka lapangan kerja baru untuk mencukupi kebutuhan jangka panjang dinyatakan sah (Qardhawi, 2002: 614-615). Bila melihat fakta sosial masyarakat sekarang ini dengan meningkatnya angka kemiskinan maka sebaiknya dana zakat yang terkumpul itu disalurkan untuk memenuhi kebutuhan yang mendesak dan untuk memenuhi tujuan yang sangat cepat yaitu hendaknya diserahkan pada orangorang fakir dan yang berhak secepat mungkin agar bisa memenuhi hajatnya dan memenuhi kebutuhan mereka. Untuk itu penulis sependapat dengan apa yang difatwakan ulama Yusuf Qardhawi bahwa Islam mewajibkan agar harta zakat itu dibagikan dengan segera dan tidak boleh ditunda-tunda pembagiannya tanpa 
adanya alasan yang jelas. Dengan semakin cepat mendistribusikannya harta zakat itu maka akan semakin baik. Karena pada zaman Nabi Muhammad dan para Khulafaur Rasyidin selalu mengutus para pekerja dan pengumpul zakat untuk segera mengambil zakat dari mereka yang memang berkewajiban untuk membayar zakat agar segera disebarkan pada orang-orang yang berhak. Mereka tidak pernah menunda dan melambat-lambatkan ( Qardhawi, 2002: 360).

Dengan menginvestasikan dana zakat dan menunda pembagiannya terhadap orang-orang fakir, menyebabkan mereka tidak menerima manfaat zakat. Sebab, perbuatan menahan dana zakat sehingga mustahiq tak dapat mengambil hasilnya, bertentangan dengan fiqih Islam. Karena banyak orang yang sangat membutuhkan dana zakat, seperti orang-orang yang kelaparan, mereka yang tidak punya pakaian, mereka yang sakit yang membutuhkan pengobatan, dan mereka yang membutuhkan tempat berlindung. Bahkan, banyak pengangguran yang membutuhkan pekerjaan dan sejumlah fakir miskin yang membutuhkan makan untuk hari ini, tidak bisa ditunda besok. Alasan-alasan seperti inilah yang tak memperbolehkan untuk melakukan penundaan pembagian terhadap hak-hak fakir-miskin, kecuali dengan alasan syar'i (Qardhawi, 2002: 362). Karena melihat kondisi ekonomi yang buruk seperti sekarang ini yang ditandai dengan meningkatnya angka kemiskinan, maka menurut penulis sebaiknya dana qardul hasan itu tidak perlu ditahan atau diinvestasikan. Dana qardul hasan, terutama dana zakatnya sebaiknya segera didistribusikan kepada yang berhak, baik itu berupa konsumtif maupun produktif.

Bantuan untuk usaha produktif ada dua model yaitu: Pertama, dana diberikan untuk menambah modal usaha yang sudah berjalan atau untuk membuka usaha kecil-kecilan. Baik itu dalam bentuk dana bergulir atau dana yang diberikan langsung tunai (carity). Bentuk produktif yang kedua yaitu dana yarig akan diberikan kepada mustahiq harus diserahtenmakan dahulu (diserahkan kepada mustahiq), baru kemudian mustahiq ditawari untuk ikut berpartisipasi dalam usaha atau tidak? Bila si mutahiq menyatakan tidak mau ikut dalam usaha, maka pihak amil tidak boleh memaksakan kehendak. Namun, bila si mustahiq menyatakan bersedia ikut dalam usaha, maka hak itu adalah hak mustahiq dan kepemilikannya adalah atas nama mustahiq. Contoh yaitu dengan membelikan alat pertanian semacam traktor, kemudian traktor itu diberikan kepada mustahiq dan mustahiq tersebut bisa memanfaat untuk produksi dengan menyewakan pada petani lain yang membutuhkan. Sedangkan hasil dari sewa itu merupakan milik penuh dari mustahiq tersebut dan kepemilikan traktor tersebut juga milik mustahiq. Dengan pendayagunaan qardul hasan seperti ini akan berdampak lebih baik yaitu 
meningkatkan taraf hidup mustahiq tersebut. Bila organisasi atau lembaga untuk menyalurkan dana yang bersumber dari zakat dengan cara meminjamkannya walaupun itu tanpa bunga, maka sebaiknya dihindari karena itu tidak ada dasar hukumnya, karena dana zakat tidak boleh ditahan dan harus segera disalurkan. Ditinjau dari sistem ekonomi Islam, zakat merupakan salah satu instrumen fiskal untuk mencapai tujuan keadilan sosio-ekonomi serta distribusi pendapatan dan kekayaan. Sebagai salah satu kebijakan fiskal, zakat (termasuk juga infak, sedekah dan wakaf) merupakan salah satu sendi utama dalam sistem ekonomi Islam yang kalau mampu dilaksanakan dengan baik akan memberikan dampak ekonomi yang luar biasa (Edwin, 2002: 2). Tujuan kegiatan zakat berdasarkan sudut pandang sistem ekonomi pasar adalah menciptakan distribusi pendapatan menjadi lebih merata. Selain untuk tujuan distribusi, analisis kebijakan fiskal dalam sistem ekcnomi pasar dilakukan untuk melihat bagaimana dampak zakat terhadap kegiatan alokasi sumber daya ekonomi dan stabilitas kegiatan ekonomi. Pengeluaran zakat adalah pengeluaran minimal untuk membuat distribusi pendapatan tetapi dampaknya tidak optimal. Karena itu, menurut Mustafa, diperlukan pengeluaran lain yang melengkapi pengeluaran zakat seperti sedekah, infak, wakaf dan sejenisnya sehingga dampaknya terhadap distribusi pendapatan bisa menjadi optimal. Selain itu, persoalan mengapa danipak ekonomi zakat relatif masih kecil, karena zakat selama ini belum dikelola secara baik dan profesional, di samping masih rendahnya kesadaran masyarakat untuk berzakat secara benar.

Memahami uraian tersebut, maka ditinjau dari perspektif ekonomi, zakat merupakan push factor bagi perbaikan kondisi masyarakat, khususnya perbaikan ekonomi, karena dengan adanya distribusi zakat akan terjadi pertumbuhan kesejahteraan masyarakat dalam arti luas. Zakat merupakan salah satu sumber keuangan berdasarkan asas keadilan dan perpaduan antara kepentingan umum (delapan asnaf mustahiq) dan kepentingan pemilik harta (muzakki) (Khallaf,1994: 113). Kelemahan organisasi pengelola dana qardul hasan terlihat dari pendapatan yang kecil karena belum bisa mengumpulkan dana secara maximum. Pengumpulan dana masih dikakukan secara pasif-reseptif. Begitu juga pendistribusiannya kurang lancar karena masih banyak dana yang tertahan. Untuk itu dana yang tertahan sebaiknya disalurkan. Karena pada dasarnya, spirit awal dari zakat itu adalah untuk membantu mereka yang benar-benar lemah dari kalangan fakir miskin. Praktek yang dicontohkan dalam sejarah menekankan sisi penyegeraan penyaluran untuk kebutuhan mendesak dan urgen, dan selebihnya baru digunakan untuk pembangunan sarana dan prasarana serta fasilitas umum atau lainnya. Kelemahan lainnya adalah dari sisi manajemen, karena seharusnya dalam 
seluruh proses kegiatan tercatat sehingga tercipta administrasi keuangan yang rapi dan pembukuan (akuntansi) yang dapat dipertanggungjawabkan, sehingga dalam menyampaikan laporan pertanggungjawaban ditandai dengan adanya catatan setiap transaksi dan disertai dengan lampiran tanda bukti.

\section{Bank Tabungan Negara (BTN) Syariah}

Dalam pendikotomian zakat setiap daerah sebagai dasar praktik yang mengharuskan suatu sistem membagikan hasil zakat kepada masyarakat sekitar yang berhak ketika harta zakat pada suatu daerah melimpah dan melebihi kebutuhan, maka akan diberikan kepada daerah yang paling dekat yang memiliki kekurangan. Dengan cara ini akan terwujud kesempurnaan dan peningkatan pada negara-negara Islam. Pembentukan sistem zakat berdasarkan ekonomi yang kuat yang tidak tergoyahkan. Demikian halnya dengan BTN Syariah Cabang Malang, dana ZIS yang didapat dari rekening-rekening ZIS disetorkan dulu ke BTN Syariah Pusat, setelah itu BTN Syariah Pusat membagi dana tersebut ke cabang-cabang sesuai dengan ketentuan / kebutuhan UKM yang akan didanai. BTN Syariah Cabang Malang mempercayakan pengelolaan ZISnya kepada Pondok Pesantren al Hikam. Rekening-rekening ZIS didapat dari rekeningrekening denda nasabah jika telat membayar dan dari pemotongan sebesar 2,5\% dari gaji karyawan serta zakat dari nasabah yang mempunyai simpanan lebih dari Rp 30.000.000 dengan menawarinya terlebih dahulu.

Besarnya pinjaman sudah ditentukan dari Bank Indonesia, yaitu sebesar Rp 1.000.000 Dana tersebut sebenarnya masih dirasa kurang bagi penerima. Bagi mereka dana sebesar Rp 1.000.000 hanya dapat digunakan untuk memenuhi biaya operasional saja, belum bisa untuk perkembangan usaha mereka. Jadi sebenarnya para UKM masih ingin mengajukan dana yang lebih besar, tetapi karena hal ini sudah ditentukan oleh Bank Indonesia permintaan tersebut tidak bisa dipenuhi. Di dalam pemberian dana pinjaman ini tidak ada kriteria, serta hak dan kewajiban bagi para UKM. Karena tidak ditentukan berapa angsuran setiap bulannya dan nasabah tidak datang langsung untuk mengangsur ke Ponpes al Hikam, tetapi pengelola dana qordhul hasan yang akan mendatangi nasabah. Untuk mengambil angsuran. Pihak pengelola telah memberikan kotak kepada para nasabah untuk dapat ditaruh dirumah, sehingga nasabah bisa mengangsurnya setiap hari dengan mengsisi kotak tersebut, yang selanjutnya setiap bulan akan diambil oleh pengelola dana. Pihak pengelola tidak menentukan berapa bulan pinjaman harus dilunasi, dikarenakan memang tidak ada aturan. Cepat dan tidaknya angsuran tergantung 
dari kemampuan penerima dana untuk mengembalikan.

\section{Simpulan}

Penyaluran dana ZIS Bank Syariah dilakukan dengan mengadakan kerja sama dengan BMT dan masjid. Penyaluran dana ZIS tersebut bersifat konsumtif dan produktif. Untuk yang bersifat produktif disalurkan kepada pemberdayaan usaha kecil mikro. Pemberdayaan yang dilakukan dengan dana ZIS tersebut adalah dengan memberikan modal guna mengembangkan usaha dan memulai usaha. Penambahan modal ini diberikan pada usaha kecil mikro agar bisa mengembangkan usaha yang telah dirintisnya. Bila usahanya berkembang, maka pendapatan akan naik dan diharapkan akan adanya transformasi dari penerima bantuan. Bila saat ini mereka diberdayakan dengan memberika suntikan permodalan bagi usaha mereka maka pada periode berikutnya mereka akan bisa untuk memberdayakan pelaku usaha kecil mikro yang lain, dengan kata lain dari mustahiq menjadi muzakki

\section{Saran}

Diperlukan pengelola dan petugas khusus yang menangani dana ZIS agar pelaksanaannya maksimal. Pekerjaan ini sebaiknya tidak hanya dilakukan sebagai tugas sambilan apalagi yang bertugas mengelola dana ZIS ini tidak diberikan insentif secara layak.

Diperlukan adanya monitoring dan evaluasi secara terus menerus sehingga target yang dicanangkan akan dapat dicapai. Kegiatan pengontrolan serta pembinaan sebaiknya dilakukan oleh orang yang berbeda sehingga kegiatan tersebut bisa dilaksanakan secara lancar dan tidak terjadi penumpukan tugas pada 1 orang.

Komunikasi antara pendamping dan peserta harus lebih ditingkatkan lagi, hal ini bisa diatasi dengan adanya pusat informasi atau bisa dikatakan sebagai customer servicenya program ini jadi setiap permasalahan para peserta bisa langsung tersampaikan.

Melakukan perluasan kerjasama dengan pihak lain, khususnya daerahdaerah yang memerlukan penyaluran dana ZIS tersebut.

\section{Daftar Pustaka}

Antonio, M. Syafi'i. 1999. Bank Syariah: Wacana Ulama dan Cendekiawan. Jakarta: Takzkia Institute.

Chapra, M. Umer. 2001. The Future of Economics: An Islamic Perspective. Jakarta: SEBI. 
Departemen Agama RI. 2002. Pedoman Zakat 9 Seri, Bagian Proyek Peningkatan Zakat dan Wakaf. Jakarta.

Esmara, Hendra. 1996. Perencanaan dan Pembangunan di Indonesia. Jakarta: Gramedia,

Kahf, Monzer. 1995. Ekonomi Islam: Telaah Analitik Terhadap Fungsi Sistem Ekonomi Islam. Yogyakarta: Pustaka Pelajar.

Laporan Badan Pusat Statistik, Sensus Ekonomi 2006 dalam Statistik UKM 2007.

Moleong, Lexy J. 2001. Metodologi Penelitian Kualitatif. Bandung: Remaja Rosdakarya.

Soeparmono. 1993. Metode Penelitian dan Survai. Yogyakarta: FE UGM.

Sumodiningrat, Gunawan dkk. 1999. Kemiskinan: Teori, Fakta dan Kebijakan, Impac. Jakarta.

Tim Pengembangan Perbankan Indonesia. 2002. Konsep dan Operasiaonal Bank Syariah, Djambatan. Jakarta.

Qardhawi, Yusuf. 2002. Fatwa-Fatwa Kontemporer 3. Terjemahan Samson Rahman dkk, Jakarta: Pustaka Al Kautsar.

Qardhawi, Yusuf. 1995. Kiat Islam Mengentaskan Kemiskinan. Jakarta: Gema Insani Press. 